'Doing research' with Gypsy-Travellers in England: reflections on experience and practice

Philip Brown and Lisa Scullion (née Hunt)

Salford Housing and Urban Studies Unit (SHUSU)

University of Salford

Salford, Greater Manchester

M5 4WT, UK

Philip Brown

Tel: + $44(0) 1612953647$

Email: p.brown@salford.ac.uk

Lisa Scullion

Tel: + $44(0) 1612955078$

Email: I.scullion@salford.ac.uk

Philip Brown and Lisa Scullion are both Research Fellows at Salford Housing and Urban Studies Unit (SHUSU), University of Salford. 


\section{‘Doing research' with Gypsy-Travellers in England: reflections on experience and practice}

\section{Abstract}

In order to bring the lives of Gypsy-Travellers in line with the sustainable communities agenda, there is now a duty for local planning authorities in England to assess the accommodation and related needs of Gypsy-Travellers. As such, there has been an increase in research which aims to 'find out' more about these communities. This article explores some of the issues that researchers should consider when carrying out research with GypsyTravellers. It focuses specifically on issues around identifying and engaging with members of the Gypsy and Traveller communities, offering some strategies and solutions based on the experiences of the authors' and other researchers.

\section{Introduction and policy backdrop}

Every now and again, a legislative change and/or policy shift acts as a catalyst for various organisations and researchers to begin 'doing research' with certain individuals, groups and/or communities. This has been the case in the United Kingdom (UK) many times over the last decade, with research focusing on, for example, asylum seekers and refugees (Robinson and Segrott, 2002; Brown, 2005; Hunt, 2008); migrant workers (Anderson et al, 2006; Jordan and Brown, 2007; Anderson, 2007); and, Gypsy-Travellers 
(Niner, 2004; Van Cleemput et al, 2007; Powell, 2008). It is this latter group who form the basis of this article.

Bancroft (2005) identifies two broad populations within Gypsy and Traveller communities. The first are Roma who are part of a recognisable culture which is distinct from the dominant society in which they live. The majority of Roma are based in Central and Eastern Europe but have also settled in the Americas, the UK and other places. Most Roma have tended to cease their nomadic way of life, often as a result of governmental policies (McCagg, 1991; Bancroft, 2005). The second broad grouping Bancroft identifies are 'GypsyTravellers'. Members of this group often share cultural characteristics and ethnic links with Roma. In addition, some Gypsy-Travellers have emerged as a result of their occupation as travelling traders and workers (Bancroft, 2005). Gypsy-Travellers, similar to Roma, are often excluded from the society and communities in which they live.

Broadly speaking, in the UK, Gypsy-Travellers have been more successful at maintaining a form of nomadism compared to populations in other countries. Furthermore, many Gypsy-Travellers in the UK are accommodated in some form of caravan based accommodation as opposed to 'bricks and mortar', which tends to be the accommodation of Central and Eastern European Roma communities. This apparent 'success' at maintaining a nomadic way of life, however, is relative and the current accommodation situation for GypsyTravellers in the UK is far from desirable, when compared to non-GypsyTraveller populations. 
Acknowledgement of this situation has brought the accommodation needs of Gypsy-Travellers onto political agenda in the UK. The policy backdrop has been comprehensively reviewed by a number of writers in recent years (Clark and Greenfields, 2006; Greenfields and Home, 2006). This article therefore does not focus on this issue; however, it is acknowledged that a certain degree of contexualisation is required in order to better understand the purpose and relevance of this article.

Most writers recognise the 1968 Caravan Sites Act as being a significant historical development in terms of the provision of culturally appropriate authorised accommodation for Gypsy-Travellers. Although this Act has its critics (Hawes and Perez, 1996), and provision was inconsistent and sometimes unsuitable, it resulted in an increase in authorised sites. At the same time, however, it gave local authorities the power to designate 'no-go' areas for Gypsy-Travellers. These were areas where it was deemed that an adequate proportion of accommodation had already been provided.

The requirement for local authorities in England and Wales to provide sites for Gypsy-Travellers ceased in January 1994, with the introduction of the Criminal Justice and Public Order Act (CJPOA) (Greenfields, 2007). Although local authorities still had powers to provide caravan sites for Gypsy-Travellers, they were under no legislative obligation to do so, and consequently few used this power. 
Furthermore, the CJPOA 1994 encouraged Gypsy-Travellers to apply for planning permission to create their own sites in areas where they frequently stopped; however, the vast majority of applications were refused planning permission (Greenfields, 2007). By the early part of the twenty-first century, the lack of authorised accommodation, coupled with the growth of the GypsyTravellers population, meant that the number of people requiring authorised places to live/stop far outweighed the number of authorised places available. Consequently, Gypsy-Travellers have been left with the following 'options': move into bricks and mortar accommodation; live on unauthorised encampments (camp on land which they do not own), which effectively equates to trailer based homelessness; live on unauthorised developments (Gypsy-Traveller owned land, which does not have planning permission); or, live on overcrowded authorised sites (see Niner, 2004a for a more detailed examination of these accommodation 'options').

There is now also broad agreement that the accommodation situation of Gypsy-Travellers in England is one of the root causes of a number of other significant problems (Crawley, 2004; Niner, 2004a; Greenfields 2009), which include: low levels of educational attainment (Bhopal, 2004); poor health chances (Van Cleemput et al, 2007); and, differential access to social care services (Cemlyn, 2008) and the services provided by local authorities (Commission for Racial Equality, 2006).

The precise legislative and policy shift within England, which brought Gypsies and Travellers under the gaze of a growing number of policy makers and 
researchers, were the Housing Act 2004, the Planning and Compulsory Purchase Act 2004, and Communities and Local Government's (CLG) Circulars 01/2006 and 04/2007. Each of these developments have a number of relevant components with a fundamental message that local authorities within England now have a duty to carry out specific Gypsy and Traveller Accommodation Assessments (GTAAs). The introduction of these assessments emerged from an acknowledgement that Gypsy-Travellers were often excluded from 'mainstream' Housing Needs Assessments, which are carried out every few years to determine the general need for housing in each local area. It was therefore decided that specific assessments were required for Gypsy-Travellers. The overarching aim of this legislation was to ensure that members of Gypsy-Traveller communities have equal access to decent and appropriate accommodation options akin to each and every other member of society.

It is the introduction of GTAAs which has created an obligation for local authorities within England, and the researchers responsible for producing them, to find out more about communities which have previously, and perhaps conveniently, been described as 'hard-to-reach'. There is an extensive and growing body of literature and research which has sought to explore different aspects of the lives of Gypsy-Travellers within the UK. Such studies have focused on examining the socio-historical background of Gypsies and Travellers (see, for example, Clark and Greenfields, 2005; Kenrick and Clark, 1999; Okely, 1983); health (Van Cleemput, 2007; Van Cleemput and Parry, 2001; Parry et al, 2004); education (Derrington and Kendall, 2007; Bhopal, 
2004; Save the Children, 2001); policing (James, 2007); social control (Richardson, 2006; Powell, 2007); and, accommodation (Crawley, 2004; Niner, 2002, 2003).

Despite this increasing focus upon Gypsy-Traveller populations, there is a void in knowledge with regards to the practicalities of carrying out research. We recognise that research is far from perfect and is often treated with suspicion by people who have been subject to some form of oppression (Smith, 2003). However, research can, and should be, a positive endeavour; its findings add to knowledge about a topic and should help to increase enlightenment by working through the dense entanglements of power and interdependencies that permeate all social relations. What is clear is that the methodological approaches adopted need careful consideration in order to generate the most effective data, as well as facilitate the most meaningful and ethical contact as possible (Garland et al., 2006).

It is anticipated that the focus upon finding out more about Gypsy-Travellers within the UK will increase at a local level (as authorities and agencies test the demand for services and impact of policies/strategies), regional level (as the accommodation and related service provision is increased), and by community development workers who will be more actively engaged in ensuring social justice prevails past the recent short-term policy movements by Government. 
This article aims to provide a range of insights for researchers and research commissioners. It is based predominantly on the authors' own work, which has been formulated out of research experience with other 'hard-to-reach' or socially excluded communities (Jordan and Brown, 2006; 2007; Hunt, 2008; Hunt and Steele, 2008), trial and error and the advice and assistance of a range people including practitioners, other academics, and Gypsy-Travellers themselves.

Naturally, there are more methodological considerations than we cover in this article; however, we aim to provide an understanding of the main methodological and pragmatic issues, as well as offering some suggestions for moving forward with research of this kind. The article purposively aims to steer away from extensively exploring prevailing theoretical, ontological and epistemological debates around research on 'race' or with minority ethnic groups (Gunaratnam, 2003 and Garland et al., 2006 offer a discussion of such issues). Exposing issues such as power, difference, gender and status is an inextricable of research and should guide all research endeavours with vulnerable or oppressed peoples. We recognise that such issues can often 'paralyse' researchers and workers with the best of intentions, raising more questions then they answer. As a result, this article takes an approach grounded in the pragmatics of 'doing research'. It is accepted and understood, however, that many of the pragmatic steps described here are entwined within theoretical complexities such as researcher subjectivities, social constructivism, and power (Brown, 2008) and we return to some of these issues later in the paper. 
A number of writers have already outlined specific methodological approaches which should be considered when working with different communities, including: asylum seekers and refugees (Bloch, 1999; Robinson, 2002); migrants (Brown, 2008); sex workers (Pitcher et al., 2008); and, community recipients of urban regeneration (Muir, 2008). Indeed, the principles behind many of the issues and suggestions made in this article could be applied to many other populations of nomadic, semi-nomadic or socially excluded groups in England and further a field.

\section{Issues, problems and strategies}

This section looks at some of the potential issues that researchers may face when undertaking research with Gypsy-Traveller populations, as well as offering some tentative suggestions for ways forward. It focuses specifically on defining Gypsy-Travellers; finding participants; sampling issues; issues of involvement, trust and power; as well as issues around reporting the findings of research.

Who to research

When faced with a research project with an apparent discrete grouping of people, such as Gypsy-Travellers, who are not only subject to a legislative definition, but also dominant cultural notions of who a Gypsy/Traveller is (Richardson, 2006), knowing who to research becomes increasingly problematic. This is further compounded as Gypsy-Travellers are not one 
homogenous group and, over time, various communities have been grouped together, rather awkwardly, due to their preference, practice or history of nomadism (Greenfields, 2007). For some Gypsy-Travellers, their identity as a Gypsy or Traveller will be grounded in ethnicity, for others it may be tradition, occupation, and/or culture. Some Gypsy-Travellers may be able to trace their family origins back a number of centuries (Clark, 2006). Similarly, others may be able to assert an association with a form of occupation (Travelling Fairs and Circuses), for which travelling is an inextricable component. Other groups of Gypsy-Travellers may be, albeit rather cursory, subsumed within the over-arching category of New Traveller (who are sometimes referred to as New Age Travellers), who tended to emerge within the UK during the 1960s and 1980s in small but significant numbers (Clark and Greenfields, 2006) and whose presence endures.

We know that identities themselves are transitory, malleable and often dependent upon the particular socio-political and historical context within which individuals are placed (Robinson, 2002). It is possible that for some people, being a Gypsy or a Traveller is an identity, whether ascribed or developed, which can be asserted or denied depending upon the perceived benefits or dis-benefits of having such an identity. For instance, GypsyTravellers who live in bricks and mortar accommodation may deny their Gypsy-Traveller identity if this is seen to serve better community relations with their neighbours. Similarly, certain individuals may assert their lineage if attending significant cultural events. Kenrick and Clark (1999) suggest that there are cultural factors which sometimes symbolise the differences between 
Gypsy-Travellers, such as distinctive economic or labour market practices, distinctive hygiene practices and the centrality of kinship networks. Broadly speaking, it is these ancestral and cultural links and also the practice and/or ideal of nomadism which is seen as a constant in the self-definition of GypsyTravellers. Over time, however, it appears that nomadism has been transformed into more of a 'state of mind' (Parekh, 2000), than a defining feature of everyday life for Gypsies and Travellers in the UK (Liégeois, 1994). Gypsy-Travellers in the UK now increasingly alternate between periods of travelling and being static.

Needless to say, defining 'who' Gypsy-Travellers are is not straightforward and when faced with 'doing research', having some clear idea about who needs to take part is fundamental to the process. In the UK, it is suggested that there are a number of broad groupings, these being: traditional Romany Gypsies (mostly English but can also be Scottish and Welsh); Irish Travellers; New Travellers; Travelling Showpeople (including Circus People); Roma; and, bargees or boat dwellers. Romany Gypsies and Irish Travellers, the two largest 'communities', are recognised as distinct minority ethnic groups, and have the full protection of the Race Relations Act (CRE, 2006). It is also anticipated that these categories will feature as ethnic groupings in the Census 2011 (Communities and Local Government, 2008).

Over time there have been various definitions of the collective term 'Gypsies and Travellers' applied for different legislative purposes, particularly in relation to housing and planning. These have varied with regards to who they include 
or exclude. At a very broad level the term 'Gypsies and Travellers' is used to encompass a variety of groups and individuals who have a tradition or practice of nomadism in common. The Housing Act 2004, referred to earlier, has provided an up-dated definition as to whom the term 'Gypsy and Traveller' refers. This definition includes all Gypsy-Travellers living in caravan based accommodation, as well as those who have ceased living in caravan based accommodation and now inhabit bricks and mortar housing. There are, of course, commentators who argue that "defining Travellers by what they do (or by folkloric expectations of their behaviour), the state has retained the power to control" (Greenfields and Home, 2006, p. 113). However, in terms of providing a clear and pragmatic definition, for those who are interested in the relationship between Gypsy-Travellers and accommodation in particular, such a definition offers a useful way forward.

\section{Sampling}

Issues associated with sampling Gypsy-Traveller communities will be more relevant to certain studies than others. Quantitative studies, for example, put particular emphasis on the representativeness of the sample in order to establish the statistical significance of findings, as opposed to the vast majority of qualitatively orientated studies where the focus is upon the richness and depth of the data (Coffey and Atkinson, 1996). The very notion of sampling implies that we know both the size and nature of the population from which the research sample is derived. With regards to Gypsy-Traveller 
communities, like many invisible or 'hard-to-reach' populations, we cannot know their size and nature with any level of certainty.

Accurately establishing a 'base population' of Gypsy-Travellers is possibly one of the most difficult things to achieve in a research project. As there are no definitive records of how many Gypsy-Travellers are currently living in England, the best estimate suggests a population of between 180,000 and 300,000 Gypsies and Travellers (Commission for Racial Equality, 2006). A significant number of people will live in caravan, chalet and vehicle based accommodation either on authorised sites or on some form of unauthorised pitch (roadside or development). In the latest available bi-annual Count of Gypsy and Traveller Caravans (July 2007), which is co-ordinated by the department for Communities and Local Government, there were 17,134 caravans recorded. This mechanism, however, is regarded as having a number of significant practical and operational problems (see Niner, 2004b). Generally speaking, ascertaining a population of 'authorised' site dwellers is relatively unproblematic as official records of local authorities can be drawn upon. Unauthorised sites are much more difficult, given their transitory nature, in the case of 'roadside' encampments, but also the fact that local authorities and stakeholders may simply not be aware of some groups/individuals hidden away within their area, either on encampments or developments.

Furthermore, there is no reliable information about the number or location of Gypsy-Travellers in bricks and mortar accommodation. Local authorities and 
other social landlords may have some information in relation to social housing allocations, or may have records indicating broad numbers. This will certainly not be the case for Gypsy-Travellers living in the private sector. Greenfields and Home (2006) have made a case for the use of data held by Traveller Education Services, who maintain a register of Gypsy-Traveller children engaged in schooling and/or home education. Whilst this is an additional useful data source, this does not tend to include children of Gypsy-Traveller families who are in an area for short periods of time, and those not engaged in schooling/education. Furthermore, it may exclude children who have been 'settled' in housing for long periods of time, as well as those individuals who do not have children. These records, like others, therefore only tend to tell part of the story and often rely on people's willingness to provide details of their ethnicity. Our experience, similar to that of Greenfields and Home (2006), is that, in reality, many individuals do not wish to provide such information due to fear of potential discrimination or harassment which, based on previous experience of members of the population, has been a sensible strategy (Ellis and McWhirter, 2008).

In essence, until data collection procedures catch-up with those applied to the 'mainstream' population, the sampling of Gypsy-Traveller populations for research has to follow a pragmatic approach.

Engaging with Gypsy-Travellers 
One of the most important issues around research with Gypsy-Traveller populations relates to finding and making contact with people. For a number of years Gypsy-Travellers have been considered as one of the communities described as 'hard-to-reach' (MORI, undated; Van Cleemput and Parry, 2001). The term 'hard-to-reach', however, sometimes reflects a lack of knowledge on behalf of the researcher about how, who and where to contact certain groups or individuals, rather than an innate inclination for separateness of the group or individuals concerned.

Inextricably linked to 'engaging' with Gypsy-Travellers is initially finding people and then making contact. Finding caravan based Gypsy-Travellers, although challenging Gypsy-Travellers, is relatively unproblematic as caravans are easily identifiable dwellings. It should be noted, however, that the authors' have experienced instances where local settled community members did not know that they were living in close proximity to an authorised Gypsy/Traveller caravan site due to the (perhaps intentionally) hidden location.

Once a site has been located, the site manager, warden or a site resident can be an excellent first point of contact in order to enable dialogue about the research. The use of such 'gatekeepers', however, is not without its problems (Bloch 1999; Robinson, 2002). Site managers and residents may 'cherry pick' people to take part in order to present a preferred 'story', or the researcher may be viewed as being in collusion with the manager/resident and therefore inhibit participation, or the content of the views which are narrated. Regardless, such an approach is a practical way of making initial contact with 
certain individuals. However, researchers should consider making contact through other means, such as local community groups, other local authority officers, health workers and education services.

With regards to unauthorised sites, as highlighted previously, these are often more challenging to locate largely due to their transitory nature or their establishment in hidden or inaccessible areas. The use of inaccessible locations tends to be driven by a desire to remain hidden in order to reduce potential complaints about their presence.

Although locating and finding caravan based accommodation has its problems, the authors have been broadly successful in achieving high rates of contact on Gypsy-Traveller sites. The greatest access problems arise when attempts are made to engage with the unknown population of Gypsy-Travellers who reside within bricks and mortar accommodation. There is a general acceptance that finding and establishing meaningful contact can be a multifaceted and intensive process, requiring pragmatism and flexibility on the part of the researcher. Greenfields and Home (2006), with reference to their work, found that making contact with 'housed' respondents was helped to a significant extent by 'snowball' sampling methods, whereby referrals were made by other respondents. The use of 'snowball' sampling is often regarded as one of the best methods of accessing hidden or vulnerable populations, in the absence of a sampling frame (Bloch, 1999). It is an approach that has been utilised within the authors' studies, coupled with the achievement of interviews through contacts of Gypsy-Travellers who have been trained and 
employed as 'Community Interviewers/researchers'. In addition, other stakeholders such as education and health workers can also be useful points of contact; however, there will be over-riding issues of data protection which need to be considered, as will the time and resource implications of assisting researchers.

The more 'traditional' methods of advertising for research participants, such as flyers and posters often have limited success, given some of the issues around literacy in Gypsy-Traveller communities. More success can be achieved by 'opportunistic sampling methods' (Home Office, 2003), whereby researchers are able to find potential participants by being in a particular location; for example, finding participants at events or sites. What is clear is that researchers need to seek multiple, and often innovative, ways to access Gypsy-Traveller populations in order to include not only those who are visible, and/or 'connected', but also those who are marginalised (Garland et al, 2006). However, simply 'accessing' Gypsy-Traveller populations will be meaningless if issues associated with empowerment are not adequately considered (Greenfields, 2007).

Involvement, trust and power

During the fieldwork of one particular study, it was suggested to the authors' that, until very recently, Gypsy-Traveller communities have been a "closed shop" and that the communities should have nothing to do with the recent waves of research. There are a number of different issues elicited by this 
remark. Firstly, until quite recently, similar to many other 'hidden' groups, Gypsy-Travellers have received very little attention with regards to their needs; indeed, they have been found to be the most discriminated communities in UK society (Stonewall, 2003; Commission for Racial Equality, 2006). When Gypsy-Travellers have been the focus of research, it has sometimes been as 'research subjects' (Greenfields and Home, 2006), rather than having an active role and being fully engaged in the research. As a result, there can be a reluctance to take part in something that is perceived to have very little effect on their lives; a perception based on sensible logic given the decreasing levels of well-being and increasing inequalities faced by Gypsy-Travellers (Cemlyn et al 2009). In some areas of the UK where the authors have worked, the increasing focus on Gypsy-Travellers has led to what Robinson (2002) describes as 'research fatigue'. Indeed, in one particular study, the attitude of some respondents was very much 'less talk, more action' as they had grown increasingly tired of being consulted with, particularly when there was very little action or change in their circumstances. Some commentators characterise this as 'helicopter research':

"where well-meaning researchers arrive, collect data, often of a descriptive kind, and leave. The community awaits the next round of research" (Smith and Pitts, 2007, p.7).

It was also not uncommon, given the increase in research with GypsyTravellers, coupled with their nomadism, for people to be interviewed more than once in separate locations. Consequently, such research can lead to 
disillusioned individuals/communities, who are less and less likely to participate in studies, despite the often well intentioned aim of most research to assist in the development and improvement of services and/or policies.

It is becoming increasingly common for researchers to offer something to research participants to compensate for their participation. As Robinson (2002) highlights:

"We need to remember that when we ask people to be interviewed we are asking them not just to tell us their stories but also give us their time" (p.65).

Some researchers offer a small token of appreciation for their time, which helps maintain a valuable research relationship, and this is endorsed by certain government departments (Robinson, 2002). Similarly, in the authors' studies, where individuals were invited to take part in interviews there was also the opportunity to enter a prize draw.

It is recognised that there are arguments against offering forms of payment to participants relating to issues of coercion. Hollway and Jefferson (2000), however, see the use of a reward/payment being intertwined with issues of power, arguing that paying interviewees helps to equalise the researcherparticipant relationship. They highlight that criticisms of payment are often linked to the perception of it influencing the free will of an individual to participate or not in a given study. However, when asking for participation in a 
study, particularly with those people experiencing financial deprivation, remuneration for their time is important, and also signifies a mark of respect for the value of their participation.

The second issue raised by the remark revolves around the suspicion of researchers (and most officialdom and 'collectors of information') in the minds of many Gypsy-Travellers, particularly with regards to the motives of the research and the use that will be made of any information obtained. As with all ethical research, there is a need to ensure that participants understand the purpose of the research and what the findings will be used for. Although these are basic requirements in order to ensure people have given their informed consent to take part in the research process, there is a wider issue of managing expectations. Research can, and does, lead to significant improvements in knowledge, policy and individual well-being. However, what must be considered is that not every piece of research will make an immediate difference to people's everyday lives, but rather may form part of a longer process of evidence-based policy making and change. The need to be transparent and realistic, in terms of expectations, is vital. If there is a mistaken belief that research will lead to an immediate change in their lives for example, the achievement of an authorised pitch - and this is not delivered, this will inevitably compound any existing inequalities, as well as creating disillusionment, as highlighted above.

Although payment is often welcomed, we have found simply 'being heard' and involved in research is sometimes worth far more. Such an approach 
demands more participatory based methods (Mayo and Rooke, 2008) and some researchers, the authors included, have begun to use this approach in research with Gypsy-Traveller communities (Greenfields and Home, 2006; Brown et al, 2007; Lomax, 2008) as one way of ensuring that the research instigates a process of empowerment for Gypsy-Travellers and enlightenment for the researchers and commissioners. Such participatory based approaches emerged originally from working with oppressed or powerless people and groups in developing countries (Fals-Borda and Anishur Rahman, 1991; Hall, 1993). Such work was significantly influenced by the work of Freire (1970), and others, and aligned with the emancipatory agendas of social movements. Maguire (1987) argues that the approach is a way for "researchers and oppressed peoples to join in solidarity to take collective action, both short and long term, for radical social change" (p. 29).

As well as the benefits this approach provides for the improvement of power relations between the 'researched' and the 'researcher', it also offers significant practical benefits. As the authors, and others, have found (Greenfields and Home, 2006), involving members of the communities who are the focus of the study in the research process helps in a myriad of ways, including: helping to ensure the questions being asked are appropriate; ensuring methods of consultation are as unintrusive as possible; providing the research team with an understanding of some of the subtle cultural 'do's and don'ts'; and, making contact with people who are either suspicious of participating, 'hidden', and/or difficult to engage. The community involvement or participatory approach is not a new one, and the success of such an 
approach is usually determined by the role of community members within the research team. Studies where community members are treated as additional interviewers may have less success and fewer benefits than those where community members have helped guide the research team throughout the research process. As Temple and Steele (2004) comment:

"research has shown that when engagement with communities is based on the long term, is adequately resourced and leads to observable change, communities become less hard to reach and less antagonistic towards future research. Such positive moves have been based on community development and capacity building rather than on parachuting in outsiders with pre-defined, often inappropriate, measurement tools and objectives" (p.553).

Within the context of research with Gypsy-Travellers, although the approach is championed by a number of researchers (Greenfields and Home, 2006), including the authors', as well as Gypsy-Traveller 'community leaders', who argue that people are reluctant to communicate with 'outsiders', the involvement of community members in research is far from unproblematic. The authors have noted that various difficult issues can arise, which include: identifying suitable potential community researchers; quality control process and consultations; achieving mutual cultural understanding; and, ensuring partnership working. Although not insurmountable, careful consideration needs to be given to how these issues are approached as they can threaten 
the validity and reliability of the research, and how it is received once completed.

Reporting the research

The final issue to be raised is inextricably linked to the entire research process and is concerned with dissemination of the research findings. For academic researchers, or academically minded practitioner researchers, dissemination typically means reporting findings in refereed articles, conference papers and/or book chapters. Such approaches, however, are clearly insufficient when trying to inform those who took the time to help generate the data for the research about its outcomes.

Furthermore, Robinson (2002) highlights concerns about researchers who "breezed in promising the earth, gained their co-operation and were never seen again" (p.65). It is therefore important that a range of strategies are adopted in order to ensure that participants have the opportunity to receive the findings of the research and that dissemination to community members is as effective as possible. Given the varying literacy levels and nomadic nature of some Gypsy-Traveller communities, this may require innovative dissemination approaches. Appropriate options may include: community reports, workshops, leaflets, audio reports, and media coverage (both specialised and general).

\section{Conclusion}


The increase in research with Gypsy-Travellers in England has highlighted, often through trial and error, some of the crucial issues to consider when researching groups who, until recently, have been relatively hidden and are often suspicious of the purpose of research.

What is apparent is that the research that has been undertaken over the past few years is by no means an end point. Rather, it is only the beginning, as local authorities, health workers, education professionals, community groups and academic researchers will all be looking in greater detail at how best to meet the myriad of needs of Gypsy-Travellers and reduce inequality. The communities who live under this generic term remain one of the most excluded communities in the UK today. Consequently, researchers need to ensure that they consider how this disempowerment impacts upon the research process and how the research process can serve as an agent of community development and social justice. Such principles of 'doing research' extend beyond Gypsy-Travellers within England or the UK and reflect the complexity of many communities across the globe.

It is hoped, and anticipated, that exclusion of Gypsy-Traveller communities will lessen over the coming years as the recent housing and planning legislation and policy takes root and the increase in suitable accommodation options impacts on other service and policy areas. Until that time, however, and possibly beyond, 'doing research' will have to be a responsible and adapted process in order for the experience and resulting findings to be 
meaningful for both Gypsy-Traveller communities and those carrying out and commissioning the research

\section{References}

Anderson, B. (2007) A Very Private Business, European Journal of Women's Studies, 14, 3: 247-264.

Anderson, B., Ruhs, M., Rogaly, B. and Spencer, S. (2006) Fair enough? Central and Eastern European migrants in low-wage employment in the UK, Oxford: COMPAS.

Bancroft, A. (2005) Roma and Gypsy-Travellers in Europe: Modernity, Race, Space and Exclusion, Aldershot: Ashgate.

Bhopal, K. (2004) 'Gypsy Travellers and Education: Changing Needs and Changing Perceptions', British Journal of Educational Studies, 52, 1: 47-64.

Bloch, A. (1999) 'Carrying out a Survey of Refugees: Some Methodological Considerations and Guidelines', Journal of Refugee Studies, 12, 4: 367-383.

Brown, P. (2005) Life in dispersal: Narratives of asylum, identity and community, Unpublished doctoral thesis, Huddersfield: The University of Huddersfield. 
Brown, P. (2008) 'Immigration, Settlement and Cultural Diversity - From

Objectivist to Interpretivist Research Methods', in P. J Maginn, S. Tonts and S. Thompson (eds) Qualitative Urban Analysis: An International Perspective, London: Routledge: 135-153.

Brown. P., Hunt, L., Steele, A. and Niner, P. (2007) North West Gypsy and Traveller Accommodation Assessments: A Good Practice Guide, Salford: The University of Salford.

Cemlyn, S. (2008) 'Human Rights and Gypsies and Travellers: An Exploration of the Application of a Human Rights Perspective to Social Work with a Minority Community in Britain', British Journal of Social Work, 38, 1: 153-173.

Cemlyn, S., Greenfields, M., Matthews, Z., Whitwell, C. and Burnett, S. (2009) Inequalities experienced by Gypsy and Traveller communities: A review, University of Bristol/Buckinghamshire New University/Equality and Human Rights Commission.

Clark, C. (2006) 'Who are the Gypsies and Travellers of Britain?', in C. Clark and M. Greenfields (eds) Here to Stay: The Gypsies and Travellers of Britain, Hatfield: University of Hertfordshire Press: 10-27.

Clark, C. and Greenfields, M. (2006) Here to Stay: The Gypsies and Travellers of Britain, Hatfield: University of Hertfordshire Press. 
Coffey, A. and Atkinson, P. (1996) Making Sense of Qualitative Data:

Complementary Research Strategies, London: Sage.

Commission for Racial Equality (CRE) (2006) Common Ground: Equality, good race relations and sites for Gypsies and Irish Travellers, London: CRE.

Communities and Local Government (2008) Government Response to: The Road Ahead: The Final Report of the Independent Task Group on Site Provision and Enforcement for Gypsies and Travellers, London: Department for Communities and Local Government.

Crawley, H. (2004) Moving Forward: The Provision of Accommodation for Travellers and Gypsies, London: Institute of Public Policy Research.

Derrington, C. and Kendall, S. (2007) 'Challenges and Barriers to Secondary Education: The Experiences of Young Gypsy Traveller Students in English Secondary Schools', Social Policy and Society, 7, 1: 119-128.

Ellis, G. and McWhirter, C. (2008) 'Land-use Planning and Traveller-Gypsies: Towards Non-prejudicial Practice', Planning Practice and Research, 23, 1: 7799.

Fals-Borda, O. and Anishur Rahman, M. (1991) Action and Knowledge Breaking the Monopoly with Participatory Action Research, New York: The Apex Press. 
Friere, P. (1970) Pedagogy of the Oppressed, New York: Seabury Press.

Garland, J., Spalek, B. and Chakraborti, N. (2006) 'Hearing Lost Voices: Issues in Researching 'Hidden' Minority Ethnic Communities', British Journal of Criminology, 46: 423-437.

Greenfields, M. and Home, R. (2006) 'Assessing Gypsies' and Travellers' needs: Partnership working and "The Cambridgeshire Project"', Romani Studies, 16, 2: 105-131.

Greenfields, M. (2007) 'Accommodation Needs of Gypsies/Travellers: New Approaches to Policy in England', Social Policy \& Society, 7, 1: 73-89.

Greenfields, M. (2009) 'Gypsies, Travellers and accommodation', Better Housing Briefing 10. Race Equality Foundation.

Gunaratnam, Y. (2003) Researching 'Race' and Ethnicity: Methods, Knowledge and Power, London: Sage.

Hall, B. (1993) 'Introduction', in P. Park, M. Brydon-Miller, B. Hall and T. Jackson (eds) Voices of Change: Participatory Research in the United States and Canada, Toronto: OISE Press. 
Hawes, D. and Perez, B. (1996) The Gypsy and the State: The Ethnic Cleansing of British Society, Bristol: The Policy Press.

Home Office (2003) One problem among many: drug use among care leavers in transition to independent living, London: HMSO.

Hunt, L. (2008) 'Women asylum seekers and refugees: Opportunities, constraints and the role of agency', Social Policy \& Society, 7, 3: 281-292.

Hunt, L. and Steele, A. (2008) Migrant workers in Rochdale and Oldham, Salford: University of Salford.

James, Z. (2007) 'Policing marginal spaces: Controlling Gypsies and Travellers', Criminology and Criminal Justice, 7, 4: 367-389.

Jordan, B. and Brown, P. (2006) 'The Sangatte Work-Visa Holders: A 'Natural Experiment' in Immigration Policy'. Parliamentary Affairs 59 (3), pp. 509-521.

Jordan, B. and Brown P. (2007) 'Migration and Work in the United Kingdom: Mobility and the Social Order', Mobilities 2 (2), pp. 255-276.

Kenrick, D. and Clark, C. (1999) Moving On: The Gypsies and Travellers of Britain, Hatfield: University of Hertfordshire Press. 
Liégeois, J. P. (1994) Roma, Gypsies, Travellers, Strasbourg: Council of Europe Press.

Lomax, D. (2008) 'Accommodating Gypsy/Travellers: Inclusive approaches for collaborative and peer-led research with Gypsy Travellers', in P. J Maginn, S. Tonts and S. Thompson (eds) Qualitative Housing Analysis: An International Perspective, London: Emerald: 161-184.

McCagg, W. (1991) 'Gypsy Policy in Socialist Hungary and Czechoslovakia, 1945-1989', Nationalities Papers Vol. 19: 313-336.

Maguire, P. (1987) Doing Participatory Research: A Feminist Approach, Amherst, Massachusetts: Center for International Education, University of Massachusetts.

Mayo, M and Rooke, A. (2008) 'Active learning for active citizenship: participatory approaches to evaluating a programme to promote citizen participation in England', Community Development Journal 43: 371-381 MORI (undated) Researching hard-to-reach and vulnerable groups, London: MORI.

Niner, P. (2003) Local Authority Gypsy/Traveller Sites in England, London: ODPM. 
Niner, P. (2002) The Provision and Condition of Local Authority

Gypsy/Traveller Sites in England, London: ODPM.

Niner, P. (2004a) 'Accommodating Nomadism? An Examination of Accommodation Options for Gypsies and Travellers in England', Housing Studies, 19, 2: 141-159.

Niner, P. (2004b) Counting Gypsies and Travellers: A review of the Gypsy Caravan Count System, London: ODPM.

Okely, J. (1983) The Traveller-Gypsies, Cambridge: Cambridge University Press.

Parekh, B. (2000) The Future of Multi-Ethnic Britain, London: Profile.

Parry, G., Van Cleemput, P., Peters, J., Moore, J., Walters, S., Thomas, K. and Cooper, C. (2004) The Health Status of Gypsies and Travellers in England, Sheffield: University of Sheffield.

Pitcher, J., Campbell, R., Hubbard, P., O'Neil, M. and Scoular, J. (2008) 'Diverse Community Responses to Controversial Urban Issues: The Contribution of Qualitative Research to Policy Development' , in P. J Maginn, S. Tonts and S. Thompson (eds) Qualitative Housing Analysis: An International Perspective, London: Routledge: 155-175. 
Powell, R. (2007) 'Civilising offensives and ambivalence: the case of British Gypsies, People', Place and Policy Online, 1, 3: 112-123.

Powell, R. (2008) 'Understanding the stigmatisation of Gypsies: Power and the dialectics of (dis)identification', Housing, Theory and Society, forthcoming.

Richardson, J. (2006) The Gypsy Debate: Can Discourse Control?, Exeter: Imprint Academic.

Robinson, V. (2002) 'Doing research' with refugees and asylum seekers', Swansea Geographer, 37: 61-67.

Robinson, V. and Segrott, J. (2002) Understanding the Decision Making of Asylum Seekers, Home Office Research Paper, London: HMSO.

Save the Children (2001) Denied a Future?: The Right to Education of Roma/Gypsy and Traveller Children, London: Save the Children Fund.

Sibley, D. (2001) 'The Control of Space: Travellers, Youth, and Drug Cultures' in D. Morley and K. Robins (eds) British Cultural Studies: Geography, Nationality and Identity, Oxford: Oxford University Press.

Smith, L.T. (2003) Decolonizing Methodologies: Research and Indigenous Peoples. London: Zed Books. 
Smith, A. and Pitts, M. (2007) 'Researching the Margins: An Introduction', in M. Pitts and A. Smith (eds) Researching the Margins: Strategies for Ethical and Rigorous Research with Marginalised Communities, London: Palgrave: 3 $-41$.

Stonewall (2003) Profiles of Prejudice: The Nature of Prejudice in England, London: Stonewall/Citizenship 21 Project.

Temple, B. and Steele, A. (2004) 'Injustices of Engagement: Issues in Housing Needs Assessments with Minority Ethnic Communities', Housing Studies, 19, 4: 541-556.

Van Cleemput. P., Parry, G., Thomas, K., Peters, J. and Cooper, C. (2007) 'Health-related beliefs and experiences of Gypsies and Travellers: a qualitative study', Journal of Epidemiology and Community Health, 61: 205210.

Van Cleemput, P. (2007) 'Health Impact of Gypsy Sites Policy in the UK', Social Policy and Society, 7, 1: 103-112.

Van Cleemput, P. and Parry, G. (2001) 'Health status of Gypsy Travellers', Journal of Public Health Medicine, 23, 2: 129-34. 